\title{
A Method for Increasing Fall Flowering in Short-day 'Carmine' Strawberry
}

\author{
Fumiomi Takeda ${ }^{1}$ \\ Appalachian Fruit Research Station, 2217 Wiltshire Road, Kearneysville, \\ WV 25430
}

\author{
Michael Newell ${ }^{2}$ \\ University of Maryland, P.O. Box 169, Queenstown, MD 21658
}

Additional index words. Fragaria, greenhouse, propagation, flower bud initiation

In the mid-Atlantic coast region, the harvest period of short-day strawberry cultivars is about 7 weeks long from early May to late June. New techniques to broaden the production period could increase yield and income and lessen the risk of weather related crop loss (Fernandez and Ballington, 2003). Cultural systems that use containerized nursery plants, annual plasticulture, floating row covers, and high tunnels have allowed facultative short-day cultivars developed elsewhere to be grown in the region and have extended the spring harvest season. There is strong market demand for locally produced fresh strawberries from September to December. Several growers in the mid-Atlantic region have grown day-neutral cultivars Seascape and Tristar under high tunnel to produce fruit during this period (B. Butler, University of Maryland Cooperative Extension Service, Westminster, MD, personal communication), but more productive cultivars are needed. The potential for short-day strawberry cultivars to flower in the fall in the mid-Atlantic coast region is an important step to meeting this need. Early flowering is feasible by exposing transplants of short-day cultivars to chilling temperatures or short-day conditions (Bish et al., 2004; Heide, 1977; Oda, 1992). However, these treatments require labor-intensive daily movement of transplants in-and-out of cold rooms or dark rooms or the drawing of a black drop cloth over the plants for up to 3 weeks. Recently, we observed that a high percentage of 8-week-old 'Chandler' transplants established in annual plasticulture produced flowers in fall but only a few of 4-week-old transplants did (Takeda, unpublished results). The objective of this study was to determine the effect of plugging date and tip size on fall flowering in 'Carmine' strawberry transplants.

'Carmine' strawberry is a short-day cultivar released in 2002 by the University of Florida (Chandler et al., 2004). On 11 Mar. 2004, containerized 'Carmine' plants produced from tissue-cultured plantlets were obtained from the University of Maryland, College Park, and placed on a greenhouse bench. In the first

Received for publication 8 Nov. 2005. Accepted for publication 10 Dec. 2005. We express our appreciations to Ann Rose for her technical support. We also thank Thomas Tworkoski and Mark Brown for their critical reviews of this manuscript and providing helpful comments.

${ }^{1}$ Research horticulturist.

${ }^{2}$ Project manager, horticultural crops week of May, they were planted in a soilless system in a greenhouse (Takeda et al., 2004). Daughter plants (runner tips) harvested on 6 to 8 July and 3 to 4 Aug. were sorted into two size classes (average about 3.0 to $6.0 \mathrm{~g}$ and small about 0.6 to $1.2 \mathrm{~g}$ ). Daughter plants were stuck in 72-cell packs and placed under intermittent mist sprinklers until some roots protruded through the drain holes at the bottom of cell pack. After that, strawberry transplants were placed on a greenhouse bench, and irrigated and fertilized as needed until 1 Sept.

Strawberry transplants were established on 2 September in a plasticulture system (Demchak, 2002) at the University of Maryland's Wye Research and Education Center (WREC) in Queenstown. The soil was a Matapeake Silt Loam that was prepared with a $16 \mathrm{~N}-8 \mathrm{P}-8 \mathrm{~K}$ preplant fertilizer applied at $450 \mathrm{~kg} \cdot \mathrm{ha}^{-1}$. The planting system consisted of raised beds, about $20 \mathrm{~cm}$ high and $73.6 \mathrm{~cm}$ wide, mulched with 1.25 mil embossed black plastic (Rain-Flo Irrigation, East Earl, Pa.). The raised beds were spaced $1.8-\mathrm{m}$ apart center to center. The plots were irrigated with a drip system with emitters at 30 -cm spacing and a flow capacity of $1.7 \mathrm{~L} \cdot \mathrm{min}^{-1}$ per30.5-m tube length(T-Systems International, San Diego, Calif.). Transplants were irrigated by overhead micro-sprinklers for $2 \mathrm{~d}$.

In this study, the four treatments were average-size tips plugged in July, small tips plugged in July, average tips plugged in August, and small tips plugged in August. Ten-plant plots were randomized in a complete block design with four replications for each treatment. The plants were arranged in offset double row spaced $30 \mathrm{~cm}$ between and in rows.

Branch crown number was measured for each plant after all runners were detached by hand on 3 Nov. On 18 Nov., we detached and counted flower buds, flowers, and green and red fruit. In Spring 2005, we harvested ripe strawberries twice weekly for 4 weeks in all plots, graded each fruit as marketable or cull, and weighed. Individual plant yield for the season was calculated.

Analysis of variance (ANOVA) for treatment was carried out using PROC GLM of SAS (2001). Calculated percentage values were transformed using arcsine of the square root of the percentage value. The treatment means were then separated with the Duncan's multiple range test $(P=0.05)$.

There was no significant block effect on the variables measured in Fall 2004 or Spring
2005. The July-plugged plants had increased their branch crown number to three by early November (Table 1). Branch crown number for August-plugged plants was just over two for the large-tip plants and only 1.6 for plants generated from small tips. Runner numbers were fewer in July-plugged transplants (2.4 per plant) than in August-plugged transplants (3.6 per plant) $(P<0.001)$. Fall flowering occurred in 83 and $85 \%$ of the transplants plugged in early July from average and small runner tips, respectively. Among August-plugged transplants, flowering occurred in only $30 \%$ of transplants produced from average tips and none of transplants produced from small tips (Table 1). In plants that flowered in fall, 12 to 13 flowers had developed on two inflorescences and by mid November, about 6 were at green and red stages of fruit development. A few reached the harvestable stage as early as 3 Nov.

In central Florida, growers plant fresh-dug 'Carmine' transplants shipped from nurseries in Canada in early October and begin harvesting fruit in December (Chandler et al., 2004).

'Conditioning' treatments for plug plants such as exposure to specific high and low temperatures (Bish et al., 2004), low temperatures, and short-day photoperiods (Heide, 1977; Oda, 1992) can hasten flowering in short-day strawberry transplants. These 'forcing' treatments involve daily manipulation of plants for 2 or 3 weeks and are generally labor-intensive. In this report, we have described a simple transplant production protocol for a facultative short-day cultivar to obtain fall flowering in high percentage of transplants. The new method does not expose transplants to either cool or cold temperatures or photoperiodic modifications to bring about fall flowering in the mid-Atlantic coast region. Fall flowering occurred in over $80 \%$ of 'Carmine' transplants when they were produced from runner tips that were plugged in early July, maintained in the greenhouse for about 8 weeks, and then field planted in early September. Typically, 4-weekold transplants are used in annual plasticulture (Durner et al., 2002), and normally they do not flower in fall under mid-Atlantic coast growing conditions.

In Spring 2005, July-plugged 'Carmine' plants produced about $875 \mathrm{~g}$ of fruit or about $160 \mathrm{~g}$ more compared to August-plugged plants (Table 1). Whether tips were plugged in July or August, higher yields were obtained in plants that were propagated from large than small tips (Table 1). The findings from this study and personal observations made in prior years indicated that the presence of fruit in the fall did not decrease spring yield. The results also suggested that spring yield was related to fall branch crown development. We are currently determining the fall yield potential and the effects of fall fruiting on yield in the subsequent spring at several locations in the south central and eastern United States using high tunnel production technique. The potential strawberry yield in fall and early winter from July-plugged, short-day strawberry cultivars can increase income for growers in the midAtlantic coast region. 
Table 1. The influence of propagation variables on crown and reproductive development in fall 2004 and yield in spring 2005.

\begin{tabular}{|c|c|c|c|c|c|}
\hline \multirow[b]{3}{*}{ Treatment } & \multicolumn{4}{|c|}{ Fall 2004z } & \multirow{3}{*}{$\begin{array}{c}\text { Spring 2005 } \\
\text { Yield } \\
(\mathrm{g} / \text { plant })^{\mathrm{y}}\end{array}$} \\
\hline & \multirow{2}{*}{$\begin{array}{c}\text { Branch } \\
\text { crown } \\
\text { (no./plant) }\end{array}$} & \multirow{2}{*}{$\begin{array}{c}\text { Fall } \\
\text { flowering } \\
\text { (\% plant) }\end{array}$} & \multicolumn{2}{|c|}{$\begin{array}{l}\text { Flower and fruit } \\
\text { (no./plot) }\end{array}$} & \\
\hline & & & Total & Red and green fruit & \\
\hline July, average & $3.2 \mathrm{a}^{\mathrm{w}}$ & $83 \mathrm{a}$ & $101 \mathrm{a}$ & $56 \mathrm{a}$ & $905 \mathrm{a}$ \\
\hline July, small & $3.0 \mathrm{a}$ & $85 \mathrm{a}$ & $113 \mathrm{a}$ & $57 \mathrm{a}$ & $844 a$ \\
\hline August, average & $2.3 \mathrm{~b}$ & $30 \mathrm{~b}$ & $35 \mathrm{~b}$ & $18 \mathrm{~b}$ & $745 \mathrm{~b}$ \\
\hline August, small & $1.6 \mathrm{c}$ & $0 \mathrm{c}$ & $0 \mathrm{c}$ & $0 \mathrm{c}$ & $681 \mathrm{~b}$ \\
\hline
\end{tabular}

${ }^{\mathrm{z} B r a n c h}$ crown and flowering plant counts taken on 3 Nov., and flower and fruit counts taken on 18 Nov.

${ }^{y}$ Total marketable yield per plant and do not include small, diseased, and misshaped fruit.

${ }^{\text {w}}$ Mean separation performed within each column by Duncan's multiple range test, $P=0.05$.

\section{Literature Cited}

Bish, E.B., D.J. Cantliffe, and C.K. Chandler. 2004. Strawberry transplant conditioning for flowering induction. U.S. Patent 6,807,769. 26 Oct.

Chandler, C.K., D.E. Legard, T.E. Crocker, and C.A. Sims. 2004. 'Carmine' strawberry. HortScience 39:1496-1497.

Demchak, K. 2002. Commercial berry production and pest management guide, 2002-2004. Pa. State Univ. Coll. Agr. Sci. AGRS -53.
Durner, E.F., E.B. Poling, and J.L. Maas. 2002. Recent advances in strawberry plug transplant technology. HortTechnology 12:545-550.

Fernandez, G.E. and J.R. Ballington. 2003. Double cropping of strawberries in an annual system using conditioned plug plants and high tunnels. Acta Hort. 614:547-552.

Heide, O.M. 1977. Photoperiod and temperature interactions in growth and flowering of strawberry. Physiol. Plant. 40:21-26.

Oda, Y. 1992. The strawberry in Japan, p. 36-46.
In: A. Dale and J. Luby (eds.). The strawberry into the 21 st century. Timber Press, Inc., Portland, Ore.

SAS Institute, Inc. 2001. The SAS system for Windows. Release 8.02., SAS Institute, Inc., Cary, N.C.

Takeda, F., S.C. Hokanson, and J.M. Enns. 2004. Influence of daughter plant weight and position on strawberry transplant production and field performance in annual plasticulture. HortScience 39:1592-1595. 